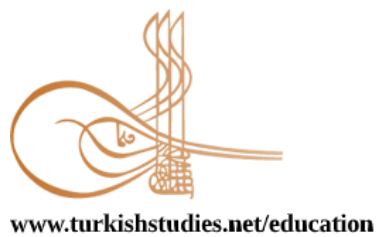

Turkish Studies - Educational Sciences

Research Article / Araşttrma Makalesi

\title{
Çocukların Trafik Bilincinin Gelişiminde Masal Türünün Rolüne Yönelik Uygulamalar
}

\author{
Applications for the Role of the Fairy Tale Type in the Development of Traffic Awareness of \\ Children
}

\author{
Erhan Akın* - Fatih Çeçen**
}

\begin{abstract}
Traffic accidents that lead to various losses occur every year in Turkey. Undoubtedly, the way to reduce these accidents at least is through o good traffic education from childhood. The earlier traffic education is given, the more permanent it affects the children. Primary school age, in which basic skills are acguired and reinforced has great importance in terms of traffic education. During the traffic education from the primary school in Turkey, it poses a requirement in terms of winning the children's traffic awareness. The contribution of the products addressing the sensitivity of the children in the delivery of traffic education is great. Taking advantage of children's products in traffic education will make the message desired to be more permanent. In this pespect; fairy tales, of one the children's literature products appear as an important genre. In this regard; it is possible to maket he traffic education and awareness gained with children's literature products are more permanent. During Turkish education and training process, tales contribute to the development of children in many areas of life. Through fairy tale texts; in this study, it is aimed to present examples of activites that are through to contribute to the development of traffic awareness of children in Turkish education and training process, within an institutional frame work. This study is a deseriptive study prepared by scanning model. These datas obtained from; Turkish teaching, four basic language skills, traffic awareness and safety issues through scientific publications, textbooks and internet. Starting from the entertaining and educational works of fairy tales, it is aimed to give children the best traffic awareness by increasing their interests and tastes with examples of fairy tales and activities.
\end{abstract}

Structured Abstract: Introduction: There are frequent traffic problems today. In order to minimize these problems, individuals should be given traffic awareness through traffic education. Traffic education can be given at an early age and traffic awareness can become more permanent. This permanence can be achieved by making various activities related to traffic education to the child from the first stage of education. Tales from children's literature are seen as an important genre in fulfilling these functions. Thanks to the entertaining function of fairy tales, the child will be able to gain traffic awareness with his fairy tale texts and events from a young age and make it applicable in all areas of his life.

\footnotetext{
${ }^{*}$ Doç. Dr. Siirt Üniversitesi, Eğitim Fakültesi, Türkçe Eğitimi Bölümü Assoc. Dr. Siirt University, Faculty of Education, Turkish Education Department ORCID 0000-0003-2372-9331

erhanakin49@hotmail.com

** Yüksek Lisans Öğrencisi, Siirt Üniversitesi, Sosyal Bilimler Enstitüsü, Türkçe Eğitimi Bilim Dalı Master Degree Student, Siirt University, Social Sciences Institute, Turkish Education Department, Turkish Education Program.

ORCID 0000-0001-6903-5234

hitaf3447@gmail.com

Cite as/ Atıf: Akın, E. \& Çeçen, F. (2020). Çocukların trafik bilincinin gelişiminde masal türünün rolüne yönelik uygulamalar. Turkish Studies - Education, 15(3), 1459-1472. https://dx.doi.org/10.29228/TurkishStudies.42807

Received/Geliş: 09 April/Nisan 2020

Accepted/Kabul: 21 June/Haziran 2020

Checked by plagiarism software

Copyright (C) INTAC LTD, Turkey

Published/Yayın: 25 June/Haziran 2020 CC BY-NC 4.0
} 


\section{The Aim of the Study}

The contribution of the products addressing the sensitivity of the children in the delivery of traffic education is great. Taking advantage of children's products in traffic education makes the massage desired to be more permanent. In this pespect; fairy tales, of one the children's literature products appear as an important genre. In this regard; it is possible to maket he traffic education and awareness gained with children's literature products are more permanent. During Turkish education and training process, tales contribute to the development of children in many areas of life. Through fairy tale texts; in this study, it is aimed to present examples of activites that are through to contribute to the development of traffic awareness of children in Turkish education and training process, within an institutional frame work. This study is a deseriptive study prepared by scanning model. These datas obtained from; Turkish teaching, four basic language skills, traffic awareness and safety issues through scientific publications, textbooks and internet. Starting from the entertaining and educational works of fairy tales, it is aimed to give children the best traffic awareness by increasing their interests and tastes with examples of fairy tales and activities.

\section{Method}

\section{Method of the Research}

This study, which contains activity suggestions prepared to create activities that can contribute to the development of children's awareness of traffic and awareness, is a descriptive study in the screening model. Data; Turkish education has been obtained by making use of scientific publications (articles, books, book chapters etc.) related to traffic awareness and awareness, internet and Turkish textbooks. A framework has been set up on what to consider in activities created by examining data sources; Activities related to traffic awareness and awareness were tried to be created in accordance with this framework. The approach defined by Sever as an "integrated approach" has been handled as a learning and teaching approach. This approach was discussed in "In teaching; full learning, effective learning, brain-based learning, multiple intelligence, constructivism; By making use of the possibilities of theories and teaching-learning approaches such as presentation, discovery, research, learning, question-answer, discussion, demonstration, cluster study, brainstorming, gamification, observation, examination, etc. in accordance with the level of students. Teaching approach using methods and techniques" (Sever, Kaya \& Aslan, 2006).

\section{Universe and Sampling}

The universe of the research is tales that are evaluated within the scope of children's literature and are appropriate for the level of children. The sample of the study consists of two fairy tale texts called "Traffic Lamp" and "Traffic Lamp Game". The tales sampled are thought to bear the common values desired to be developed in children with the fiction and features of the fairy tale genre.

\section{Data Collection and Analysis}

In order to create a theoretical framework, first of all, books, theses, articles and other information sources about traffic awareness and education and fairy tales were scanned. After this stage, two fairy tale texts called "Traffic Lamp" and "Traffic Lamp Game" were obtained (masalsitesi.com). In the study, preliminary readings were made to determine the appropriateness of the texts provided. Based on the fairy tale texts "Traffic Light" and "Traffic Light Game", various activities were prepared for the development of children's traffic awareness. While preparing the activities, the age groups and levels of the students were taken into consideration. It was concluded that it would be more effective to benefit from the fairy tale type since it appeals to the world of imagination and has an entertaining feature as well as it contains educational features.

\section{Findings and Comments}

Aforementioned; It is important for the person who breaks the traffic light in the fairy tale text called "Traffic Light" to regret the action and apologize from the traffic light, and to show the children the good, the right and the beautiful ones in the fairy tale text called "Traffic Light Game". As in the aforementioned fairy tale texts, the tales will always give the children the feature of being a good traffic factor and will have a good traffic awareness from a young age, with the function of the wicked losing in the tales. Given the age levels and basic needs of children, it is seen that fairy tales will make a great contribution in terms of raising awareness and awareness of traffic in this context. These activities, which are prepared for the development of children's traffic awareness of fairy tales, are examples and suggestions. 
In her 2007 study, Çetinkaya states that children have the opportunity to get to know life and self with the experiences they have from fairy tales, and this situation directs their behavior. It emphasizes that the behaviors, messages and values that are desired to be brought to the child become concrete through the events in fairy tales (Çetinkaya, 2007). In addition, Görgü identified the children in the 2006 study with the people in the fairy tale; It states that it has the opportunity to get to know and evaluate itself, it can change its behavior positively, it is socialized and it can adapt to society in this way, it has the opportunity to acquire civilized behaviors and to recognize and adopt universal and national values (Görgü, 2006, p. 551). This situation reveals the importance of our study.

\section{Conclusion and Suggestions}

Children should be informed about traffic starting from primary school period, they should be protected from traffic accidents or they should be raised to protect themselves. Starting from pre-school period, education can be provided to the children to raise their awareness in this field. It is important to develop the beliefs and attitudes of individuals in a positive way during childhood, when the personality is gained. In this critical period, it should be ensured that it meets or brings together literary products addressing the child's sensitivity. The literary products that the child is in the center and written for children provide the opportunity to recognize the values, culture and beliefs of the society in which the child lives. Tales, which are among children's literature, take an active role in fulfilling these functions. Child readers can recognize and internalize the values and culture of the society they live in in the tales they read and make them applicable in daily life. Tales that nurture and enrich the imagination of children, tell the truth in different ways and ensure that children are prepared for the future are the best children's works that reflect childlike sensitivity. Various tales are taught to the children, and their creativity is improved and they offer different solutions to the problems. Fairy tales are children's products that play an important role both in education and culture of children. In this respect, fairy tales are not ignored as a folklore product necessary for child education in terms of adopting both national and universal values.

In this study, it is emphasized that it would be appropriate to use fairy tale texts related to traffic so that children have a good traffic awareness. Based on the features of fairy tales, it is thought that it will be more effective to gain traffic awareness to children with the activities prepared based on two fairy tale texts called "Traffic Light Game" and "Traffic Light", and thus, children will be the practitioners of this awareness in the future.

The texts should be supported with literary genres that are suitable for the level of the child and can be enjoyed in order to give children traffic awareness. The type of fairy tale should be at the top of these. Fairy tale texts on traffic education should be included in textbooks. Cartoons that will improve traffic awareness should be designed through fairy tales and these fairy tales should be shown on screens. Theoretically, traffic education should be given as applied. In this study, it is seen that the most important aim is to increase the traffic awareness and awareness of children by making lessons more enjoyable and fun with the examples of activities presented through fairy tale texts to develop traffic awareness of children.

Keywords: Children's literature, traffic education, traffic awareness, tale, children.

Öz: Türkiye'de her yıl çeşitli kayıplara yol açan trafik kazaları meydana gelmektedir. Bu kazaları en aza indirmenin yolu şüphesiz çocukluktan itibaren iyi bir trafik eğitiminin verilmesinden geçmektedir. Trafik eğitimi ne kadar erken yaşlarda verilirse çocuklarda daha çok kalıcı etki bırakır. Temel becerilerin kazanıldığı ve pekiştirildiği ilköğretim çağı, trafik eğitimi açısından büyük önem taşımaktadır. Türkiye'de ilköğretim döneminden itibaren verilen trafik eğitimi, çocukların trafik bilincini kazanması açısından bir gereklilik arz etmektedir. Trafik eğitiminin verilmesinde çocuğun duyarlılığına seslenen ürünlerin katkısı büyüktür. Trafik eğitiminde çocuk ürünlerden yararlanmak verilmek istenen mesajın daha kalıcı olmasını sağlayacaktır. Çocuk edebiyatı ürünlerinden olan masallar bu yönüyle önemli bir tür olarak karşımıza çıkmaktadır. Bu bakımdan çocuk edebiyatı ürünleri ile kazandırılan trafik eğitimini ve bilincini daha kalıcı hale getirebilmek mümkündür. Türkçe eğitimi ve öğretimi sürecinde masallar çocukların hayatın birçok alanında gelişimine katkı sağlar. Masal metinleri aracılığıyla, bu çalışmada Türkçe eğitimi ve öğretimi sürecinde çocukların trafik bilincinin gelişimine katkıda bulunabileceği düşünülen etkinlik örneklerinin kuramsal çerçevede sunulabilmesi amaçlanmıştır. Bu çalışma tarama modeliyle hazırlanmış betimsel bir çalışmadır. Veriler; Türkçe öğretimi, dört temel dil beceresi, trafik farkındalığı ve güvenliği konularındaki bilimsel yayınlardan, ders kitabından ve 
internetten yararlanılarak elde edilmiştir. Masalların eğlendirici ve eğitici işlevinden hareketle çocuklara masal metinleri ve etkinlik örnekleriyle onların ilgi ve zevklerini arttırarak trafik bilincini en iyi şekilde kazanmaları hedeflenmiştir.

Anahtar Kelimeler: Çocuk edebiyatı, trafik eğitimi, trafik bilinci, masal, çocuk.

\section{Giriş}

Trafik Kanunu'na göre yollardaki yayaların, hayvanların ve araçların karayolları üzerindeki hal ve hareketlerine trafik denir (Karayolları Trafik Kanunu, 1983). Çocuklar doğduğu andan itibaren kendini bir çevrenin içerisinde bulur. Yaşadığı çevre itibariyle çocukluktan başlayarak trafikle tanışmaya ve trafikle iç içe yaşamaya başlar. Çocuğun bulunduğu çevrede güvenli bir şekilde yaşamını sürdürmesi önemlidir.

Çocuğun yaşadığı çevre itibariyle sürekli etkileşim halinde olduğu trafikte yaşama hakkını güvenli kılmanın en güzel yolu okul öncesi eğitim dönemi ile trafik bilinci oluşturulması ve trafik eğitiminin verilmesidir(Sarıçiçek ve Bekir 2018). Okul öncesi dönem kültür taşıyıcısı ve geleceğin yetişkinleri olan çocukların trafik hakkında bilgilendirilmeleri ve bilinçlendirilmeleri bakımından en önemli dönem olarak yansıtılmaktadır (Hatipoğlu, Özdemir ve Öztürk 2012). Çocuğun trafikle iç içe yaşaması ve yaşadığı topluma uyum sağlaması beraberinde trafikle ile ilgili bazı kuralların benimsenmesini zorunlu kılmaktadır. Bu kuralların benimsenmesi de ancak trafik eğitimiyle mümkün k1lınabilmektedir.

Trafikle beraber ortaya çıkan düşünce ve eylem karmaşasının eğitimle çözüme kavuşturulması gerekmektedir (Balkız, 1999). Erken yaşlarda verilen trafik eğitimiyle bireyin kazandığı bilinç ve sorumluluk daha çok etkili olmaktadır. Çocuklara küçük yaşlardan itibaren trafikle ilgili eğitim verilmesi ve onların bu doğrultuda yönlendirilmesi, onların trafik kazalarından zarar görme riskini azaltmakla beraber, 15-20 yıl sonrasının sürücülerin ve yayalarının da eğitimli ve sorumluluk sahibi bireyler olmalarına katkıda bulunacaktır (Hatipoğlu, 2002).

Erken yaşlarda verilmeyen trafik eğitimi hayatın ileriki dönemlerinde birçok sıkıntıları da beraberinde getirmektedir. İyi bir trafik eğitimi verilmemiş bir toplumda trafik konusunda ciddi bir şekilde bilinç eksikliği görülür. Gerekli trafik bilinci kazanamamış bir toplum da sık sık trafik kazalarıyla karşı karşıya kalmaktadır. Türkiye'de 0-14 yaş grubundaki çocukların trafik kazaları sonucu hayatını kaybetme oranı gelişmiş ülkelere oranla çok yüksektir. Bu durum, ülkemizde verilen trafik eğitimi ve trafik güvenliği konusunda yetersiz olduğumuzu gözler önüne sermektedir (Karabey, 2006).

Trafikte meydana gelen kazaları azaltmanın en önemli yolu bireylerin trafik farkındalığ 1 ve bilinci konusunda bilgilendirilmelerini sağlamaktır. Çocukların gelecekte trafikte sürücü, trafiği denetleyen, hatta trafik düzeni hakkında karar veren konumda olacakları düşünüldüğ̈̈nde çocukların doğru ve kalıcı bir trafik farkındalığına sahip olması trafik sorunlarını başlangıçta çözmesi açısından büyük öneme sahiptir. (Çelik, Aral, ve ark., 2018). Trafik farkındalığı ve bilinci kazanan çocuk, artık yetişkinleri trafikteki davranışları konusunda doğru bilgilerle yönlendirebilme imkanını elde etmiş olacaktır (Gürsoy vd., 2015). Trafik unsurunu hayatının bir parçası haline getiren bireyler bu sayede trafikle daha barışık bir yaşam geçirirler. Eğitimle beraber trafiği yaşadığı kültürün bir öğesi haline getiren bireylerin trafik kurallarına daha çok uyum sağladığı da görülecektir.

Trafiğe yönelik problemlerin ana kaynağı olarak, kent kültürünün yarattığı birlikte yaşama arzusunun tüm dünyada zorunlu kıldığı kurallara, özellikle de trafik kurallarına uyma konusunda gösterilen isteksizlik gösterilebilir (Pampal ve ark., 1999). Trafiğin en önemli unsuru olan insan faktörü göz önünde bulundurulduğunda ise eğitim faktörünün daha çok ön plana çıktığı söylenebilir. Trafikte meydana gelen kazalarını önlemenin yolu trafik güvenliğini sağlamakla mümkün hale gelir. Trafik güvenliğini sağlamak karayollarındaki kurallara uymakla mümkün hale gelir. 
Karayollarındaki kurallara uyum sağlamak ise bireyin edindiği trafik kültürüne bağlıdır. İyi bir trafik kültürüne sahip olmak da ancak eğitimle sağlanır (Başköy, 2005: 41). Yüksek bir trafik bilincine sahip, ölüm oranı düşük olan ülkelerin trafik eğitimine bakıldığında; konunun okul öncesi eğitim döneminden itibaren en önemli öğe olarak ele alındığı görülmektedir (Pampal, 2011). Bu açıdan bakıldığında çocuğun okul öncesi dönemden itibaren sağlam bir trafik eğitimi alması ve trafik kültürünü edinmesi gerekmektedir.

Trafik eğitimi, gerek eğitim kurumlarında gerek eğitim kurumları dışında bireylerin trafik ve trafik kazaları konusunda bilinçlendirmelerini sağlamak, onlara gereken bilgi ve becerileri sunarak trafikle ilgili problemlerin önlenmesi için onlara gerekli olan davranışları kazandırmaktır. Başka bir deyişle trafik eğitimi; "yasal koşulların belirlediği trafik kurallarını, kişinin yaşantısı sırasında doğal davranışlar şekline dönüş̧ürebilmek, kiş̧ilerin can ve mal güvenliğini sağlamak için yapılması gereken çalışmaların tümüdür” (Sönmez, 1991).

Çocuğun iyi bir trafik bilincine sahip olması için sadece okulda verilen trafik eğitimi yeterli değildir. Çocuk gerek yaşadığı çevrede gerekse yaşadığ ailede trafik konusunda bilgilendirilmeli ve bunu günlük yaşamının bir parçası haline getirmelidir. Verilen trafik eğitimin bir ders olmasından öte yaşam boyu devam bir bilinç kazandırma işlevi olduğunun çocuğa hissettirilmesi de ayrıca bir anlam ifade etmektedir. Bu anlamda eğitim kurumlarında verilen güvenli trafik eğitimine, sadece bir ders olarak bakılmamalı, "çocuklarda güvenli trafik bilinci oluşturma platformu" şeklinde bakmak gerekmektedir (Yetkin ve Daşcan, 2008: 1283).

Türkiye'de trafik kültürünün oluşması ve trafikle ilgili sorunların kalıcı olarak ortadan çözülebilmesi toplumsal bilinçlenmenin sağlanmasıyla mümkün olur ancak (Pampal ve ark., 1999). Çocuğun doğumundan itibaren onu geleceğe hazırlayan, eğiten, hayal dünyasını zenginleştiren ve bunları yaparken de onu eğitme görevi üstlenen bir öğretim yöntemi olan masallar, mezara kadar devam eden süreçte bireyin birçok alanda bilinçlenmesine katk1 sağlar. Bu sebeple çocuğun karşılaştığı ilk ürünler olan masallar çocuklara trafik bilincini kazandırma bağlamında önemli bir tür olarak karşımıza çıkmaktadır. Halkın hayal gücünün bir ürünü olan ve ortak yaratısından doğmuş, ağızdan ağza aktarılan ve kuşaktan kuşağa geçen, kahramanları ejderha, peri, cin, dev, arap bacı gibi olağanüstü kişiler olan hikâyeler şeklinde tanımlaması yapılan masallar, ortak bir kültür taşıyıcısı olma görevi taşımaları sebebiyle değerler eğitiminin kazandırılmasında aktif bir görev üstlenmektedir (Şimşek, 2007).

Masallarda iyi-kötü, doğru- yanlış, genç-yaşl1, yoksul-zengin, çirkin- güzel (Şimşek, 2007) gibi karşıtlıkların yer alması, çocuğa birçok alanda değerlendirme yapma ve farklı değerleri karşılaştırma imkânı tanımaktadır. Ayrıca masallardaki kahramanların olağanüstü özellikler taşımaları çocukların ilgisini çekmeyi başarır. Masal, çocukların ruh yapısına dokunmakla hayal dünyalarını zenginleştirdiği gibi çocuğu geleceğe hazırlar. Masallardaki sembolik unsurlar ayıklandığında ortaya gerçek hayat çıkar. Böylece çocuk kendi dünyasına seslenen masallarla, kendisini geleceğe taşıyan tecrübeleri bu yönüyle edinmiş olur (Karatay, 2007). Bu açıdan bakıldığında masallar değerlerin benimsenmesi bağlamında çocuklara trafik eğitimi ve bilincini kazandırma açısından faydalı olacaktır.

\section{Yöntem}

\section{Araștırmanın Yöntemi}

Çocukların trafik bilinci ve farkındalığı kazanma konusundaki gelişimine katkı sunabilecek etkinlikleri oluşturmak amacıyla hazırlanan etkinlik önerilerini içeren bu çalışma tarama modelinde betimsel bir çalışmadır. Veriler; Türkçe öğretimi, trafik bilinci ve farkındalığı ile ilgili bilimsel yayınlardan (makale, kitap, kitap bölümü, vb.), internetten ve Türkçe ders kitaplarından yararlanılarak elde edilmiştir. Veri kaynaklarının incelenmesiyle oluşturulan etkinliklerde göz önünde bulundurulması gerekenler konusunda bir çerçeve oluşturulmuş; trafik bilinci ve farkındalığı 
ile ilgili etkinlikler, bu çerçeveye uygun bir şekilde oluşturulmaya çalışılmıştır. Sever'in "bütünleştirilmiş yaklaşım” şeklinde tanımladığı yaklaşım, öğrenme ve öğretme yaklaşımı olarak ele alınmıştır. Ele alınan bu yaklaşım "Öğretimde; tam öğrenme, etkin öğrenme, beyin tabanlı ögrenme, çoklu zekâ, yapılandırmacılık; sunuş yoluyla, buluş yoluyla, araştırma yoluyla ögrenme gibi kuram ve ögretme-öğrenme yaklaşımlarının olanaklarından yararlanılarak öğrencilerin düzeyi ve onlara kazandırılacak davranışların niteliğine uygun olarak soru-yanıt, tartışma, gösteri, küme çalışması, beyin firtınası, oyunlaştırma, gözlem, inceleme vb. yöntem ve tekniklerin kullanıldı̆̆ yaklaşımı" dır (Sever, Kaya ve Aslan, 2006).

\section{Evren ve Örneklem}

Araştırmanın evrenini çocuk edebiyatı ürünleri kapsamında değerlendirilen ve çocukların seviyesine uygun olan masallar oluşturmaktadır. Araştırmanın örneklemini ise " Trafik Lambası "ve "Trafik Lambasının Oyunu" adlı iki masal metni oluşturmaktadır. Örnekleme alınan masalların, masal türüne ait olan kurgu ve özelliklerle çocuklarda geliştirilmesi istenilen ortak değerleri taşıdığ1 düşünülmektedir.

\section{Verilerin Toplanması ve Analizi}

Kuramsal bir çerçeve oluşturmak amacıyla öncelikle trafik bilinci ve eğitimi ve masallarla ilgili kitap, tez, makale ve diğer bilgi kaynakları taranmıştır. Bu aşamadan sonra "Trafik Lambası" ve "Trafik Lambasının Oyunu" adlı iki masal metni elde edilmiştir (masalsitesi.com). Çalışmada, önce temin edilen metinlerin uygunluğunu belirlemek amacıyla ön okumaları yapılmıştır. Elde edilen "Trafik Lambası" ve "Trafik Lambasının Oyunu" adlı masal metinlerinden yola çıkılarak çocukların trafik bilincinin gelişimine yönelik çeşitli etkinlik örnekleri hazırlanmıştır. Etkinlikler hazırlanırken öğrencilerin yaş grupları ve seviyeleri göz önünde bulundurulmuştur. Çocukların hem hayal dünyasına hitap etmesi hem de eğlendirici bir özellik taşımasının yanında eğitici özellikler barındırması sebebiyle masal türünden faydalanılmasının daha etkili olacağı sonucuna varılmıştır.

\section{Bulgular ve Yorumlar}

Söz konusu; "Trafik Lambası" adlı masal metninde trafik lambasını kıran kişinin yaptığı hareketten pişman olması ve trafik lambasından özür dilemesi ile "Trafik Lambasının Oyunu" adlı masal metninde trafik lambasının yaptığı hatanın farkına varıp özür dilemesi çocuklara iyiyi, doğruyu ve güzel olanı göstermesi açısından önemlidir. Sözü edilen masal metinlerinde de olduğu gibi masallarda kötülerin daima kaybetmesi iyilerin ise kazanması işlevinden de hareketle masallar, çocuklara daima iyi bir trafik unsuru olma özelliği kazandıracak ve küçük yaşlardan itibaren iyi bir trafik bilincine sahip olmalarını sağlayacaktır. Çocukların yaş seviyeleri ve temel ihtiyaçları göz önünde bulundurulduğunda masallar bu bağlamda çocuklara trafik bilinci ve farkındalığı kazandırma açısından büyük bir katkı sunacağı görülmektedir. Masalların çocukların trafik bilincinin gelişimine yönelik hazırlanan bu etkinlikler bir örnek ve öneri niteliği taşımaktadır.

Çetinkaya, 2007 çalışmasında çocukların masallardan edindiği deneyimlerle yaşamı ve kendini tanıma imkânı elde ettiğini ve bu durumun davranışlarına yön verdiğini belirtmektedir. Çocuğa kazandırılmak istenilen davranışların, iletilerin ve değerlerin masallarda geçen olaylar aracılığıyla somut hale geldiğine vurgu yapmaktadır (Çetinkaya, 2007). Ayrıca Görgü, 2006 çalışmasında çocukların masaldaki kişilerle kendini özdeşleştirerek; kendini tanıma ve değerlendirme imkânı elde ettiğini, davranışlarını olumlu yönde değiştirebildiğini, toplumsallaştığını bu yolla da topluma uyum sağlayabildiğini, uygar davranışlar kazanıp evrensel ve ulusal değerleri tanıma ve benimseme olanăg 1 bulabildiğini belirtmektedir (Görgü, 2006, s.551). Bu durum çalışmamızın önemini ortaya koymaktadır.

\section{Trafik Lambast}

"Bir zamanlar ülkelerin birinde, belki de bizim ülkemizde bir trafik lambası varmış. Yaz kış durup dinlenmeden çalışır dururmuş. Yine bir gün lapa lapa kar yağmasına karşın, 
görevi başındaymış trafik lambası. Arabalar vızır vızır geçerken yayalar geçitte yeşil ışı̆̆ bekliyorlarmış. Durmadan kar yağdı ̆̆ için de her zamankinden daha öfkeliymişler. Biri, "Bu karda da trafik lambasının yeşil ışık yakmasını beklemek zor geliyor" diye söyleniyor; bir başkası "Dondum vallahi. Bozuldu mu nedir? Ne diye adım başına bir trafik lambası dikerler anlamadım gitti." diye atıliyormuş.

Trafik lambası bir an üzülmüş. "Ben onlar için çalışayım, onlar beni azarlasın. Olur mu ya?" demiş kendi kendine. Ama yine de düzeninin bozmadan çalışmasına devam etmiş. Bir süre sonra, önce sarı ışığını, sonra da yayalara yeşil ışığını yakmış. Yayalar hızlı hızlı karşıya geçerken bu kez de arabalardan biri homurdanmaya başlamış: "Kim bu trafik lambasını buldu bilmem ki. Zaten yerde kar var, vızır vizır kaylyor. Tam hızlandığım sırada bu kez de şıp diye kırmızı ışık yanıyor. Dur durabilirsen artık. Şeytan diyor ki, git çarp, yık şu lambalarl” demiş. Güngörmüş bir dolmuş arabası bu sözleri söyleyen taksiye yan gözle bakmış, "Zincirlerin nerede? Zincirlerin olsaydı karda kayıyorum diye trafik lambasını suçlamazdın. O olmasaydı, hele böyle bir havada birbirimize girerdik" diye onu azarlamış. Azarlamış ama taksi yine de trafik lambasına sayıp dökmüş. Zavallı trafik lambası özellikle havanın karlı yağmurlu olduğu günlerde hep böyle sözlerle karşılaşırmış. O gün de öyle olmuş işte. Ama gündüz iş öyle çokmuş ki trafik lambası bu sözleri düşünecek zaman bile bulamamış. Ama gecenin geç saatlerinde sokaklar boşalmış da, o da rahat bir soluk alabilmiş. Hoş yine düzenli aralıklarla yanıp sönüyormuş ama gürültü yokmuş, bağıran çağıran da yokmuş. Trafik lambası o zaman tasalı tasalı, "Bugün herkesten azar işittim. Arabalar bir türlü bağırdl, yayalar başka türlü. Ama hiç biri benim görevimi yaptı̆̆ımı düşünmedi” diye içini çekmiş. Hem yayaları hem arabaları aynı anda mutlu etmenin olanaksızlı̆̆ını bildiği için "Ne yapsam boşuna” demiş.

İşte tam o sırada da "çat" diye bir taşın, kırmızı lambasının camına vurmasıyla bağırmış: “Ah, gözüm.” Kırmızı ışık o anda sönüvermiş tabii. Trafik lambası acıyla, korkuyla inlerken arsız bir ses duymuş. Bu arkadaşlarının, "bodur bacak" dedikleri haylazın biriymiş: "Hah hay! Tam ortasından vurdum. Dikkatli bakın şimdi ikinci atacağım taş da tam yeşil lambanın üstüne vurmazsa bana da nişancı bodur bacak demesinler. Atıyorum." diye bağırmış. Zavallı trafik lambası çaresizlik içinde çevresine bakınmış. Ama böyle karlı bir havada kim çıkar dışarı? Koca cadde bomboşmuş. Bodur bacağın savurduğu taşlar sonunda yeşil ve sarı lambalarını da kırınca trafik lambası sönüvermiş. Bodur bacak ve arkadaşları da, "Yarın sabah rahat rahat geçer gideriz caddelerden. Yaşasın!” diye kahkahalar atarak çekip gitmişler.

Trafik lambası bütün gece karın altında inlemiş durmuş. Ama onu asıl üzen, ertesi gün görevini yapamayacağıymış. Derken gün ışımış. Yavaş yavaş bomboş caddeleri insanlar, taşıtlar doldurmaya başlamış. Trafik lambası korku içinde onlara bakıyor, "Keşke kaza filan olmasa" diyormuş. Evet, kaza filan olmamış. Olmamış ya, iki saat içinde trafik arap saçına dönmüş. Taşıtlar birbirlerine girmişler. Hepsi birden kızgın kızgın korna çalıyorlarmış. Insanların durumu daha da kötüymüş. Bir türlü karşıdan karşıya geçemiyorlarmış. Geçmeye kalkanlar da birden firlayan bir arabanın altında kalmaktan ya zor kurtuluyor ya da üstü başı çamur içinde kalıyormuş. Kısacası ortalık tam bir curcunaya dönmüş. Her kafadan bir ses çıkıyormuş. Biri, "Meğerse bu trafik lambası, ne gerekli şeymiş. On beş dakikadır karşıya geçemiyorum” diyormuş. Bir başkası, "Bir an önce onarsalar bari" diye yakınıyormuş. Ne ileri ve ne de geri gidebilen arabalar "dart dart" diye korna çalarken taksi, "Hay dilim tutulsaydı da trafik lambasına kötü söz söylemeseydim” diye kendi kendine kızıyormuş. Neyse ki, trafik lambasını kısa bir süre sonra onarmışlar da her şey düzene girmiş. O günden sonra da kimse trafik lambasından yakınmamış. Onun ışıklarının sözünden dışarı çıkmamış, herkes sırasını beklemiş", (masalsitesi.com). 


\section{Etkinlik 1}

Aşağıdaki soruları okuduğunuz/dinlediğiniz metne göre cevaplayınız.

1.Trafik lambasının görevi neymiş?

2.Trafik lambası neden durup dururken üzülmüş?

3. Trafik lambası neden korku içinde yoldan geçen insanlara ve taşıtlara bakıyormuş?

4. Siz bir trafik lambası olsaydınız ne hissederdiniz ?

\section{Etkinlik 2}

Okuduğunuz/dinlediğiniz metne göre aşağıda yer alan sözcükleri, sözcük avı yaparak işaretleyelim.

\begin{tabular}{|c|c|c|c|c|c|c|}
\hline$\ddot{U}$ & M & B & K & I & Y & G \\
\hline S & A & R & I & K & E & Ş \\
\hline Y & Y & E & R & L & S & Ö \\
\hline A & U & O & M & D & I & N \\
\hline Y & Z & Z & I & E & L & I \\
\hline A & Y & N & Z & I & V & Ş \\
\hline L & A & Z & I & H & E & I \\
\hline C & T & R & A & F & I & K \\
\hline
\end{tabular}
1. YEŞİL
2. SARI
3. KIRMIZI
4. IŞIK
5. TRAFIK
6. YAYA

\section{Etkinlik 3}

Aşağıda $5 \mathrm{~N} 1 \mathrm{~K}$ yöntemine göre verilen soruları metinden hareketle yanıtlayınız.

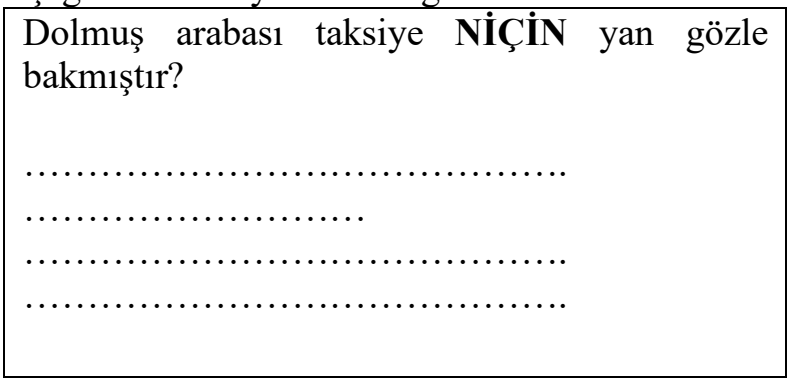

Arabalar vızır vızır geçerken yayalar

NEREDE yeşil ışığı bekliyorlarmış?

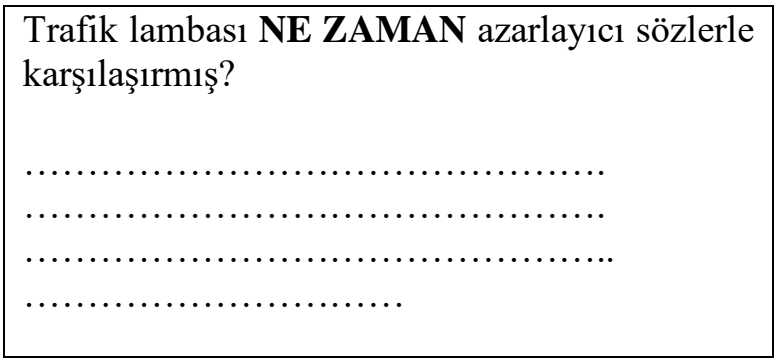

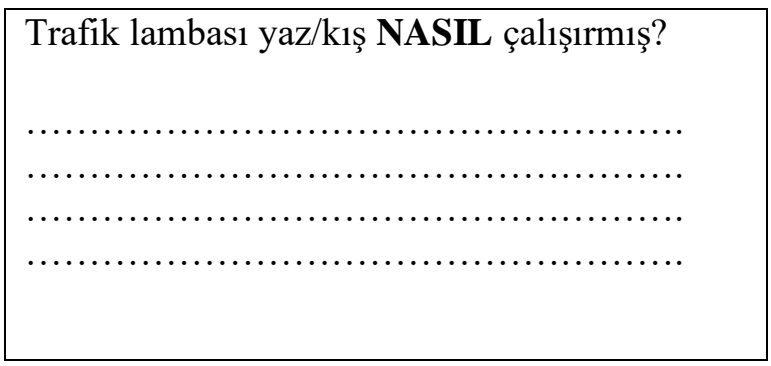




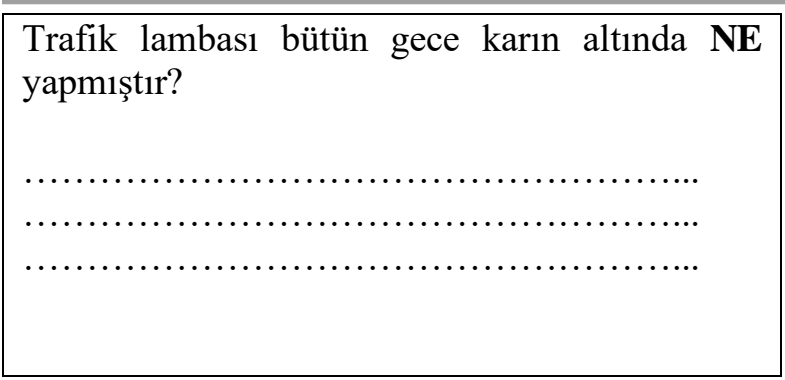

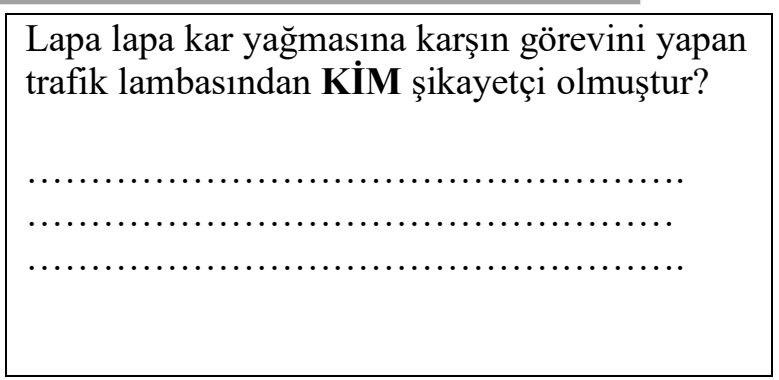

\section{Etkinlik 4}

Okuduğunuz/dinlediğiniz “Trafik Lambası" adlı masal metninin size çağrıştırdığı duyguları ve kavramları yazınız.

\section{Çağrıştırdığı duygular}

\section{Çağrıştırdığı kavramlar}

\section{Etkinlik 5}

Okuduğunuz metinle ilgili olan görsellerin altına " $X$ " işareti koyunuz.
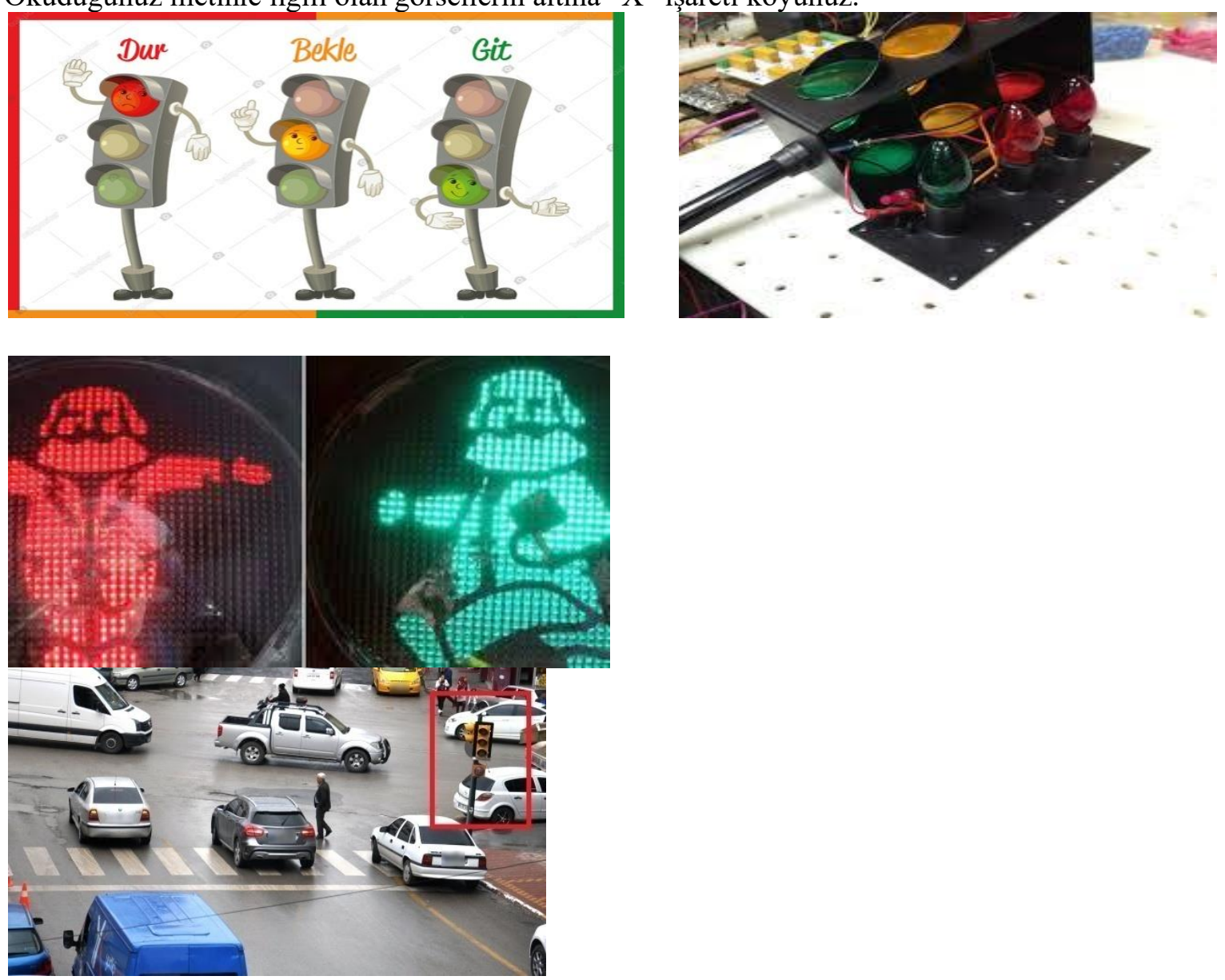

\section{Etkinlik 6}

\section{Ĕgleniyorum ve Öğreniyorum}

"Çocuklar ögretmen karşısında yan yana dururlar. Her biri bir aracı canlandırır. Ögretmen trafik lambalarının renkleri olan kırmızı, sarı ve yeşil renklerinden birine sahip olan bir nesne söyler. Çocuklar söylenen nesnenin rengini düşünür ve rengi trafik ışı̆̆ 
gibi düşünerek uygun davranışta bulunurlar. Örneğin çilek denmişse kırmızı ışı̆̆ın gereği dururlar, çimen denmişse yeşil ışığın gereği harekete geçerler. En sona kalan kişi oyunu kazanır" (vuslatanaokulum.com).

\section{Trafik Lambasinin Oyunu}

"O gün hava çok güzeldi. Menekşe sokağındaki trafik lambasının canı çok sıkılıyordu. Her gün aynı şeyleri yaptığını ve kimsenin onu fark etmediğini düşünüyordu. Bir oyun oynayacaktı. Kırmızı yanması gereken lambayı yeşil, yeşil yanması gereken lambayı sarı, sarı yanması gereken lambayı da kırmız yakmaya karar verdi. Oyuna daha yeni başlamıştı ki ortalık birden çok karıştı. Yaramaz trafik lambası meraklı gözlerle etrafina bakıyor ve neler olduğunu anlamaya çalışlyordu. Trafik lambası şaşkındi. Bu kadar olaya neden olabileceğini hiç düşünmemişti. Olay yerine hemen trafik polisleri geldi. O sırada üzgün duran trafik lambasını gördüler. Trafik polisi lambaya' 'Yaptıklarını görüyor musun?" diye kuzdl. Trafik lambası ne diyeceğini bilmiyordu. "Bu kadar önemli iş yaptığımın farkında değildim. Her gün aynı şeyleri yapıyorum. Kırmızı lambayı yakıyorum duruyorlar. Sarlyı yakıyorum bekliyorlar. Yeşili yaklyorum geçiyorlar. Onlar da aynı şeyleri yapmaktan sikılmışlardır, belki oyun oynamak isterler diye düşündüm."dedi. Trafik polisi: "Sen bir trafik lambasisın. Bu yüzden kurallara uyup görevlerini yerine getirmelisin. Ĕger görevini yapmazsan trafik karışır."dedi. Trafik lambası çok üzgündü. Yaptı̆̆ı hatanın farkına varmıştı. Herkesten özür diledi", (masalsitesi.com).

\section{Etkinlik 1}

Okuduğumu anladım ve cevap vermek istiyorum.

1.Trafik lambasının canı neden sıkılıyormuş?

2. Trafik lambasının bir anda şaşkın olmasının sebebi neydi?

3.Trafik polisi lambaya niçin kızmış olabilir?

4. Trafik lambasının canı sıkıldığı için yaptığı doğru mu, siz olsaydınız ne yapardınız?

\section{Etkinlik 2}

Okuduğum/dinlediğim metne göre aşağıdaki uygun kutucuğa ' $\mathrm{X}$ ' işareti koymak istiyorum.

\begin{tabular}{|c|c|c|}
\hline & Doğru & Yanlıs \\
\hline Trafik 1şıklarının renk sıralaması önemli değildir. & & \\
\hline Sarı 1şık yanınca geçmek için hazırlanmalıyız. & & \\
\hline Kırmızı 1şık yanınca durmalıyız. & & \\
\hline Bazen yeşil 1ș1kta durmalıyız. & & \\
\hline $\begin{array}{l}\text { Trafik lambalarının görevlerini yerine getirmeleri güzel } \\
\text { bir davranıstır. }\end{array}$ & & \\
\hline
\end{tabular}

Turkish Studies - Education, 15(3) 


\section{Etkinlik 3}

Okuduğunuz metinden hareketle üç soru hazırlayıp bu soruları cevaplamama yardımcı olur musunuz?

\begin{tabular}{|l|l|l|}
\hline \multicolumn{2}{|l|}{ Sorularm } & Cevaplarm \\
\hline 1 & & \\
\hline 2 & & \\
\hline 3 & & \\
\hline
\end{tabular}

\section{Etkinlik 4}

İyi trafik bilincine sahip bireylere ait olan davranışları işaretleyelim mi?

O Kırmızı 1şık yanınca dururlar.

O Yeşil 1şık yanınca geçerler.

O İnsanlar karşıya geçerken beklemezler.

O Trafik ışıklarının yanması için beklemeye gerek duymazlar.

O Her trafik ışığının bir görevi olduğunu bilirler.

O Trafik lambaları bazen yanmazsa da sorun etmezler.

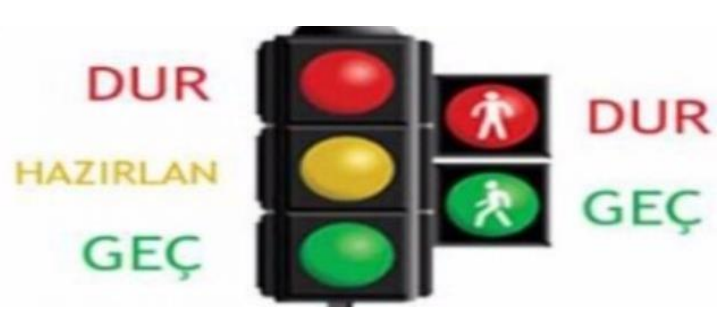

\section{Etkinlik 5}

Çocuklara "Trafik Lambasının Oyunu" adlı kısa filmi izletildikten sonra çocuklar aşağıdaki etkinliği yaparlar. (Temel Eğitim Genel Müdürlüğü)

\section{Öğrenme Süreci ${ }^{1}$}

"Çocuklara çeşitli trafik işareti levhalarının olduğu görseller gösterilir. Bu görsellerin ne olduğu, üzerindeki işaretlerin ne anlama geldiği, üzerinde yazılanların ne anlama gelebileceği sorularak sohbet başlatılır. Görsellerle ilgili merak ettiklerini sormaları istenir.

- Trafikte nelere dikkat edilmesi gerektiği, trafik kurallarına uymazsak neler olabileceği, trafikte insanların nasıl saygılı olabilecekleri konuşulur. Trafik kurallarına uymanın herkesin sorumluluğu

\footnotetext{
${ }^{1}$ Bu bölüm www.eba.gov.tr adresinden alınmıştır.
} 
olduğu vurgulanır.

- Trafik ışıklarının hangi renk olduğu ve renklerin hangi anlama geldiği hakkında sohbet edilir.

Trafik polisi resmi gösterilerek görevleri hakkında sohbet edilir.

- "Trafik" isimli şarkı hareketleriyle birlikte söylenir.

Trafik

Kırmızıda asla geçmem (İşaret parmağı iki yana sallanır)

Sarı yanar beklerim (Eller bele konur beklenir)

Yeşil yanınca ise

Durmadan ilerlerim (Yerinde yürüyüş hareketi yapılır)

Kurallara uyarım,

Uymayana kızarım. (Kızma mimiği yapılır)

Kurallara uyanı

Her zaman alkışlarım (Alkış yapılır)

- Şarkının ardından masalara geçilir. Trafik ışığı modeli çocuklara gösterilir. Sırasıyla üsttekinin kırmızı, ortadakinin sarı, alttakinin yeşil olduğu vurgulanır. Kırmızı, sarı ve yeşil renkteki pullar dağıtılır. Trafik ışığı modeline bakarak üstten alta (kırmızı-sarı-yeşil) olmak üzere "Çılgın Trafik Işıkları" örüntü çalışma sayfasını yapmaları istenir" (eba.gov.tr).

\section{Değerlendirme}

"• Bugün hangi trafik işaretlerini öğrendik?

- Trafik işaretleri olmasaydı neler olurdu?

- Trafik polisinin görevleri nedir?

- Trafik 1şıkları olmasa yayalar/sürücüler ne zaman geçebileceğini nasıl anlayabilirlerdi?

- Trafik 1şıklarına dikkat etmeyen yayalar/sürücüler seni duyabilselerdi onlara ne söylemek isterdin?

- Çevrende başka hangi trafik işaretlerini görüyorsun?

• Trafik ışıklarının sırası nasıl olmalıdır?" (eba.gov.tr).

\section{Desteklenen Değerler}

"Sorumluluk: Etkinlik sırasında sürücülerin çevreye, yayalara ve hayvanlara karşı saygıll olmaları yayaların da trafik işaretlerine uyarak sürücülere ve çevreye saygı ve sorumluluklarını yerine getirmeleri gerektiği anlatılabilir. Trafik kurallarına uymanın toplumsal bir sorumluluk olduğu vurgulanabilir." (eba.gov.tr)

\section{Sonuç ve Öneriler}

İlköğretim döneminden itibaren çocukların trafik konusunda bilgilendirilmeleri ile bilinçlendirilmeleri, trafik kazalarından kendilerini korumaları veya kendilerini koruyacak şekilde yetiştirilmeleri gerekmektedir. Okul öncesi dönemden başlayarak çocuklara verilen eğitimle çocukların bu alanda bilinçlendirilmeleri sağlanabilir. Kişiliğin kazanıldığı çocukluk döneminde bireylerin edindiği inanç ve tutumların olumlu yönde geliştirilmesi önem taşımaktadır. Bu kritik dönemde çocuğun duyarlılı̆̆ına seslenen edebi ürünlerle buluşması veya buluşturulması sağlanmalıdır. Çocuğun merkezde olduğu ve çocuklar için yazılan edebi ürünler, çocuğun içinde yaşadığı toplumun değerlerini, kültürünü ve inançlarını tanıma imkânı sağlamaktadır. Çocuk edebiyatı ürünleri arasında yer alan masallar bu işlevleri yerine getirmede aktif bir rol üstlenmektedir. Çocuk okurlar, okudukları masallarda yaşadığı toplumun değer yargılarını ve kültürünü tanıyıp içselleştirerek günlük hayatta uygulanabilir hale getirebilmektedir. Çocukların hayal dünyasını besleyip zenginleştiren, gerçeği farklı yollardan anlatan ve çocukların geleceğe hazırlanmasını sağlayan masallar, çocuksu duyarlılığı yansıtan en iyi çocuk eserleridir. Çocuklara çeşitli masallar okutularak, onların yaratıcılıklarının geliştirilmesi ve sorunlara farklı çözümler getirmeleri hem çocukların hem de insanlığın geleceği itibariyle önemli bir kazanım sunmaktadır. Masallar, 
çocukların gerek eğitimlerinde gerekse kültürlenmelerinde önemli görevler üstlenen çocuk ürünleridir. $\mathrm{Bu}$ yönü itibariyle masallar, çocukların hem milli hem de evrensel değerleri benimsemeleri açısından çocuk eğitimi için gerekli bir halk bilimi ürünü olduğu göz ardı edilmemektedir.

$\mathrm{Bu}$ çalışmada çocukların iyi bir trafik bilincine sahip olmaları için trafikle ilgili masal metinlerinden yararlanmanın uygun olacağı üzerinde durulmaktadır. Masalların bünyesinde barındırdığı özelliklerden hareketle "Trafik Lambasının Oyunu" ve "Trafik Lambası" adlı iki masal metninden yola çıkılarak hazırlanan etkinliklerle çocuklara trafik bilinci kazandırılmasının daha etkili olacağı ve bu sayede çocukların gelecekte bu bilincin uygulayıcısı olacağı düşünülmektedir.

Çocuklara trafik bilinci kazandırmak için metinler çocuğun seviyesine uygun ve zevk alabileceği edebi türlerle desteklenmelidir. Masal türü bunların başında gelmelidir. Ders kitaplarında trafik eğitimi ile ilgili masal metinlerine çokça yer verilmelidir. Masallar aracıllı̆ııly trafik bilincini geliştirecek çizgi filmler tasarlanmalı ve bu masallar ekranlarda gösterilmelidir. Teorik olarak verilen trafik eğitiminin uygulamalı olarak da verilmesi gerekir. Bu çalışmada çocukların trafik bilincini geliştirmek için masal metinleri aracılığıyla sunulan etkinlik örnekleri ile derslerin daha zevkli ve eğlenceli hale getirilerek çocukların trafik bilinci ve farkındalığının arttırılması en önemli amaç olarak karşımıza çıktığı görülmektedir.

\section{Kaynakça}

Aral, N., Aydın, R., Bekir, H., Çelik, F.T. (2018). Okul Öncesi Eğitime Devam Eden Çocukların Trafik Farkındalığının Bazı Değişkenler Açısından İncelenmesi (Şanlıurfa Hilvan Örneği). Çocuk ve Gelişim Dergisi (ÇG-D), 1(1), 43-51.

Balkız, C. (1999). İlköğretimde Trafik Eğitiminin Trafik Kazalarının Önlenmesi Üzerindeki Etkileri. Yayınlanmamış Yüksek Lisans Tezi, Gazi Üniversitesi, Fen Bilimleri Enstitüsü.

Başköy, F. (2005). Medyadaki Trafik Konulu Haberlerin İçerik Analizi, Yüksek Lisans Tezi, Gazi Üniversitesi Fen Bilimleri Enstitüsü.

Çetinkaya, Z. (2007). “Masalların Türkçe Öğretimindeki Yeri ve Önemi”, Doktora Tezi, Dokuz Eylül Üniversitesi, Eğitim Bilimleri Enstitüsü.

Çiğiltepe, A. (1998). İlköğretim Çağındaki Çocukların Trafik Eğitimleri. Yayınlanmamış Yüksek Lisans Tezi, Gazi Üniversitesi, Fen Bilimleri Enstitüsü.

Fişek, O. “Trafik Lambası”, (Erişim Tarihi 20.11.2019), https://oya.fisek.net.

Görgü, A. T. (2006). Masalların Çocuğun Bilişsel ve Duyuşsal Gelişimine Katkısı. II. Ulusal Çocuk ve Gençlik Edebiyatı Sempozyumu içinde (s. 537- 544). Ankara Üniversitesi Eğitim Bilimleri Fakültesi Yayınları.

Hatipoğlu, S. (2002). Okul Öncesi Çocuklarda Trafik Eğitiminin Gerekliliği. Uluslararası Trafik ve Yol Güvenliği Kongresi Bildirileri Kitabı (ss. 501-505) Gazi Üniversitesi Trafik Planlaması ve Uygulamas1 Anabilim Dal1.

Hatipoğlu, S., Özdemir, S., Arıkan Öztürk, E. (2012). Türkiye"ede ilköğretim okullarında verilen trafik eğitiminin farklı ülkelerde verilen eğitimle karşılaştırılarak incelenmesi ve geliştirilmesi için öneriler. Abant İzzet Baysal Üniversitesi Eğitim Fakültesi Dergisi, 12(2), 9-22.

Karabey, A. L. (2006). 2004 Yılı İçinde Meydana Gelen Trafik Kazalarından 14 Yaş ve Altı Çocukların Etkilenmelerinin İncelenmesi, Yayımlanmamış Yüksek Lisans Tezi, Gazi Üniversitesi Fen Bilimleri Enstitüsü. 
Karatay, H. (2007). Dil Edinimi ve Değer Öğretimi Sürecinde Masalın Önemi ve İşlevi. Türk Eğitim Bilimleri Dergisi, 5(3), 463-475.

Karayolları Trafik Kanunu (1983). Madde 3, Kanun Numarası: 2918, Kanun Kabul Tarihi: 13/10/1983, Yayımlandığı Resmi Gazete Tarih: 18/10/1983, Yayımlandığı Resmi Gazete Sayıs1: 18195, http://www.trafik.gov.tr (20.01.2011).

MEB (Milli Eğitim Bakanlığı). (2019). Ortaokul ve İmam Hatip Ortaokulu 5.Sınıf Türkçe Ders Kitabı. Cem Web Ofset A.Ş.

Pampal, S., Hatipoğlu, S., Arıkan Öztürk, E., Yıldız, E. (1999). Türkiye'de Trafik Probleminin Nedenleri: Bilinç Eksikliği ve Yetersiz Eğitim, II. Ulaşım ve Trafik Kongresi Bildiriler Kitab1 27- 33.

Pampal, S. (2011). Trafik Kazaları ve Çocuklar, Ankara Trafik Vakfı Dergisi, Sayı: 42, Yı1: 9, Başyazı.

Sarıçiçek, T., Bekir, H. (2018). 5 yaş çocuk resimlerinde trafik. II. Uluslararası Sınırsız Eğitim ve Araştırma Sempozyumu (USEAS 2018) bildiri özetleri kitabı içinde (ss. 215). Sınırsız Eğitim ve Araştırma Derneği.

Sever, S., Kaya, Z., Aslan, C. (2006). Etkinliklerle Türkçe Öğretimi. Morpa Yayınları.

Sönmez, V. (1991). Okul Öncesi ve Temel Eğitimde Trafik Eğitiminin Önemi. 1. Trafik Şuras1 Bildiriler Kitabı, (ss. 392-393). EGM Trafik Daire Başkanlığı.

Şimşek, T. (2007). Çocuk Edebiyatı (4. Basım). Suna Yayınları.

Temel Eğitim Genel Müdürlüğü, “Trafik Hayattır”, (Erişim Tarihi: 21.11.2019), http://okuloncesi.eba.gov.tr.

“Trafik Lambasının Oyunu”, (Erişim Tarihi: 20.11.2019), https://www.masalsitesi.com.

Yetkin, D., Daşcan, Ö. (2008). Son Değiş̧ikliklerle İlköğretim Programı 1- 5 Sınıflar (Güncellenmiş 2. Bask1), An1 Yayınc1lk. 